\title{
Human Capital Resourcing Practices and Organisational Performance: A Study of Selected Organisations in Lagos State, Nigeria
}

\author{
Christopher Odogwu Chidi ${ }^{1}$ and Okwy Peter Okpala ${ }^{2}$ \\ ${ }^{1}$ Department of Industrial Relations \& Personnel Management \\ University of Lagos, \\ ${ }^{2}$ Department of Accounting, University of Lagos, \\ Nigeria
}

\section{Introduction}

Organisations are microcosms of society. They are our source of niche as well as our source of scourge (Chidi \& Ogunyomi, 2010). What a paradox? It is a truism that organisations are the dominant feature of our society. According to Etzioni (1964, p.1), "our society is an organisational society. We are born in organisations, educated by organisations, and most of us spend much of our lives working for organisations. We spend much of our leisure time paying, playing, and praying in organisations. Most of us will die in an organisation, and when the time comes for burial, the largest organisation of all- the State must grant official permission". "Organisations are social units (or human groupings) deliberately constructed and reconstructed to seek specific ends or goals" (Etzioni, 1964, p.2). For organisations to meet their goals, they should be able to attract qualified and competent human capital. There is a popular maxim that the human capital is a source of competitive advantage. This is the view of the resource-based theory. The focus of this study is on recruitment and selection which are subsets of human capital resourcing practices; and to examine their relationship with organisational performance. Organisational performance has been the focus of intensive research efforts in recent times. How well an organisation implements its policies and programmes and accomplishes its strategic intent, in terms of its mission and vision is of paramount concern. Managers and administrators in both private and public organisations are becoming increasingly aware that a critical source of competitive advantage does not often come from product and services, best public relations strategy or state-of-the-art technology but from having an appropriate system of attracting and managing the organisation's human resources (Oladipo \& Abdulkadir, 2011).

Many scholars have viewed the concept of organisational performance from different perspectives, and this has been problematic since there are no universal or unified criteria for measuring the concept of organisational performance. Researchers have used financial 
and non-financial metrics to measure organisational performance. Financial measures include profit, sales, and market share. Non-financial measures include output or productivity, quality, efficiency, and the attitudinal and behavioural measures such as commitment, intention to quit, and satisfaction (Khan, 2010). Dimensions of organisational performance could therefore be financial and non-financial. Wang, Chich-Jen, and Mei-Ling (2010) citing Choi and Mueller (1992) argue that an enterprise should simultaneously consider financial and non-financial indices for performance evaluation. In other words, qualification and quantification factors should be considered at the same time, because such non-financial indices as employee morale and product quality are very important for its long-term operation.

The absence of good human capital resourcing practices could lead to dysfunctional or negative organisational outcomes and high rates of employees' separation (voluntary and involuntary). Organisations try to avoid the need for involuntary separation and to minimise voluntary separation especially among top performers as both kinds of turnover are costly (Noe, Hollenbeck, Gerhart \& Wright, 2004). Haphazard human capital resourcing and separation of valued employees could be insidious to the well-being of organisations the world over. In some organisations, be it unionised or non-unionised, public or private, manufacturing or service-oriented, the human capital resourcing function is conducted in a haphazard and informal fashion. More so, nepotism, favouritism and god-fatherism have been rife in the execution of human capital resourcing function in some organisations. According to Fashoyin (2005), recruitment and selection are heavily influenced by relations rather than by objective assessment of the suitability of the job applicant. Thus, family affiliation and friendship have substantial influence. These may lead to negligent hiring with adverse implications for employees' satisfaction, retention as well as organisational performance. In spite of such challenges, researches on effective human capital resourcing are few. According to Ploy hart (2006), in spite of the critical needs for effective staffing practice, many organisational decision makers overlook the need for staffing research necessary to identify research-practice gaps. Such studies are imperative to abridge the theory-practice gaps in human capital resourcing practices in Nigerian workplaces. An organisation reputable for incessant voluntary labour turnover will find it extremely difficult to attract talents or prospective applicants from the external labour market. Dreher and Dougherty (2002) argue that voluntary turnover is costly because replacements must be recruited, selected and trained. Thus, an excessive voluntary turnover rate can disrupt the social and communication patterns among stayers and increase stayers' workloads and stress levels. The escalation in the rate of labour turnover is a grave concern for organisations. Dess and Shaw (2001) opine that voluntary turnover represents significant direct costs (replacement, recruitment, selection, temporary staff and management time); indirect costs (staff morale, pressure on remaining staff, cost of training, product/ service quality and organisational reputation) and loss of social capital.

According to Peretomode and Peretomode (2001), the efficiency and effectiveness of any work place (whether the private or the public sector) largely depend on the calibre of the workforce. The availability of a competent and effective labour force does not just happen by chance but through an articulated recruitment exercise. Recruitment is the process of 
announcing job vacancies with a view to attracting a pool of qualified applicants to fill up vacancies in an organisation. It is regarded as a positive process. According to Etomi (2002), recruitment is concerned with the process of attracting a sufficient number of individuals with the right profile in terms of qualifications, experience, skills and other relevant attributes to indicate their interest in working for an organisation. Recruitment is the process of generating a pool of qualified applicants for organisational jobs (Mathias \& Jackson, 2004). Selection is the process of evaluating those who have been searched for and obtained through recruitment with a view to deciding whether they can be employed or not. It is also the process of choosing the individual or individuals who best meet the job-related criteria. "Selection is a decision-making activity: the psychological calculation of suitability" (Price, 2004, p.408). According to Yoder and Staudohar (1982, p.169) "selection is the process in which candidates for employment are divided into two classes - those who will be offered employment and those who will not"

The objective of this paper is to examine human capital resourcing practices and organisational performance in selected organisations in the food, beverage and tobacco industry in Lagos State, Nigeria.

\section{Literature review}

Attempt is made to review some theoretical and conceptual issues, as well as empirical studies germane to human capital resourcing practices. Human capital is the bedrock upon which all other organisational resources rest upon. Bontis, Dragonetti, Jacobsen and Roos (1999) view human capital as representing the human factor in the organisation; the combined intelligence, skills and expertise that gives the organisation its distinctive character. The human elements of the organisation are those that are capable of learning, changing, innovating and providing the creative thrust which if properly motivated can ensure the long-term survival of the organisation. According to Armstrong (1998), the word resourcing describes what managers need to do to ensure that they get the people they want in terms of numbers, skills and capabilities. This entails forecasting requirements, job analysis, recruitment and selection. Price (2004) views employee resourcing (human capital resourcing) as the process by which people are identified and allocated to perform necessary work. Thus, resourcing has two strategic imperatives: first is to minimise employee costs and to maximise employee value to the organisation; and secondly to obtain the correct behavioural mix of attitude and commitment in the workforce. Katou (2008) views human capital resourcing as comprised of recruitment, selection, separation and flexible work arrangements. This study leans on the following theories; the resource-based view or theory, contingency theory, universalistic theory and decision-making theory. Theoretical framework provides the explanations on which a study is based (Oyeniyi, 2006). What follows is an examination of the theoretical underpinnings of the study.

\section{- Resource-based view or theory}

Human resource has been regarded as an important factor for an organisation to gain competitive advantages and realise organisational goals or targets as advanced by the resource-based theory (Barney, 2001). This theory holds the view that the strategic 
capability of an organisation is dependent on its resource capability in the shape of people (Armstrong, 2009). The resource-based theory provides the rationale for human capital resourcing. It maintains that the long-term competitiveness of a company depends upon the resources that not only differentiate it from its competitors, but are also durable and difficult to imitate and substitute. The resource-based view, advocates that an organisation can gain competitive advantage by attracting and retaining best human resources.

\section{- Contingency theory}

Contingency theory states that the relationship between the relevant independent variables (e.g HRM policies and practices) and the dependent variable (performance) will vary according to the influences such as company size, age, technology, capital intensity, degree of unionisation, industry/sector, ownership and location (Paauwe, 2004). This theory holds the view that human resource management is influenced by the organisation's environment and circumstances (Legge, 1978; as cited in Armstrong, 2009). This is also true for human capital resourcing practices and organisational performance since they cannot exist in a vacuum but within an operating milieu or environment. Organisational performance is influenced by variables viewed as contingencies (Katou, 2009). This supports the argument of Kuchinke (2003) that organisations do not operate in a vacuum.

\section{- Decision-making theory}

The basis of the decision-making theory is the fact that decision- making is at the very heart of business success of any organisation (Gberevbie, 2006). For this study, the decisionmaking theory is adopted because human capital resourcing which promotes the achievement of organisational goals and objectives entails management decision. Thus, the more quality a decision taken by an organisation is, particularly as regards who to hire and from what source, the higher their profitability and productivity (Gberevbie, 2006). Noe, Hollenbeck, Gerhart, and Wright (2004) observed that through personnel selection, organisations make decisions about who will or will not be allowed to join the organisation. This theory assumes that decision-making is the essence of all human resource management actions and processes. It also assumes that decisions are rational and that managers examine the pros and cons of taking a particular decision.

\section{- Universalistic theory}

The universalistic theory is associated with terms such as best practices and high performance work practices. It assumes that there is a linear relationship between HR practices or systems and organisational performance and that best practices are universally applicable and successful. It posits that organisational success is best measured in terms of financial performance indicators like profits, or by market share and sales levels. Universalistic theorists are Osterman (1994), Pfeffer (1994) and Huselid (1995).

What follows are empirical studies which have established connections between human capital resourcing practices and organisational performance. Delany and Huselid (1996) 
established that practising an effective recruitment and selection process has positive relationship with organisational performance. Researchers have found a positive and statistically significant association between use of recruitment and selection procedure and profits (Terpstra \& Rozell, 1993). A good recruitment exercise enhances productivity. It also reduces cost as it reduces labour turnover rate and employee dissatisfaction (Nwachukwu, 2000). In a study in Greece, Katou and Bedhwar (2006) found that staffing and other HRM practices such as training and promotion, involvement of employees, incentives, safety and health have positive relationship with firms' performance. Gberevbie (2010), in a study on strategies for employee recruitment, retention and performance in the Nigerian civil service, argued that for an organisation to realise its goals, appropriate strategies for employee recruitment and retention are sine-qua-non for enhanced performance. In a study on recruitment, and quality of academic staff selection, the case of Covenant University, Nigeria; Gberevbie (2006) declared that the success and failure of any organisation to a greater extent depend on the quality of its work-force arising from the level of importance attached to the recruitment of its work-force. Gberevbie (2006) further observed that there is a linkage between labour sourcing decision and organisational performance. The linkage is contingent on the fact that for organisation to achieve its goals, labour sourcing decisions on where to get quality staff and when to hire them become very crucial to the performance and survival of the organisation. In a similar vein, Armstrong (2001) observed that employee resourcing strategy is a vital part of both the formulation and implementation of business strategies needed to achieve organisational performance/effectiveness.

Selection has been found to be positively related to firm performance (Terpstra \& Rozell, 1993). Researchers found a positive relationship between effective recruitment and selection practices and top-class performance (Harel \& Tzafrir, 1996; Delany \& Huselid, 1996). Selective selection is negatively related to employee turnover and is positively related with perceived profit, market share and investments in the near future (Verburg, 1998). Fajana (1995) noted that in the selection process of small and medium enterprises (SMEs) and some large enterprises (LEs), selection was often based on subjective criteria as interviews, psychological tests and medical examinations were ignored or not formally or seriously executed. References were sometimes asked for but not given proper consideration or scrutiny. From empirical research, firm size is very important for the formalisation of HR policies and practices. Hornsby and Kurato (1990) analysed personnel policies and activities on five important aspects namely; job analysis and job description, recruitment and selection, remuneration, training and performance assessment. They found that sophistication of personnel activities were directly linked with firm size. The bigger the company the more sophisticated and extensive were the policies and activities in use. Thus, with increasing size, HR policies and activities become more complex, more formalised and sophisticated. If an organisation hires an applicant without checking his/her references and background and the applicant later commits a crime while in the employ of the organisation, the organisation may be found guilty of negligent hiring (Aamodt, 1999). From experience, reference checks is one of the selection tools usually taken for granted by many organisations. The danger of this attitude towards reference checks could be negligent hiring. Dessler (2008) defined negligent hiring as hiring 
workers with questionable backgrounds without proper safeguards. Negligent hiring is injurious to the organisation, customers and co-workers. Aamodt (1999) suggested that employers via the HRM department should obtain information about the quality of previous performance by relying on an applicant's references from previous employers. Ahmed and Schroeder (2003) investigated the effect of selective hiring on organisational performance (quality, cost, flexibility, delivery and commitment). The study confirmed a positive and significant relationship with firms' operational performance. Delaney and Huselid (1996) reported that selectivity in staffing is positively related to firm performance. Employees could be hired via sophisticated selection procedures designed to screen out all but the very best potential employees that would impact on the bottom line.

\subsection{Research hypotheses}

Two research hypotheses were formulated for the purpose of this study and both tested at $5 \%$ level of significance. The authors hypothesised:

i. That there is a positive relationship between recruitment practices and organisational performance.

ii. That there is a positive relationship between selection practices and organisational performance.

\section{Methods}

The study adopted the descriptive or survey research design. There are other research designs such as observational and experimental designs. The justification for choosing the survey method is based on the fact that the study is interested in gaining an understanding of the problem being investigated without any attempt to manipulate or control the sample subjects (Asika, 1991). More so, the focus of the study is to examine the attitude or opinion of respondents as opposed to their behaviour. The survey method is ideal since large sample of respondents are required and the researchers are interested in subjecting the collected data to rigorous statistical analysis and hypotheses testing. Primary, secondary and tertiary sources of data were utilised. With a view to eliciting information from respondents, a self-developed questionnaire was designed using the 4point Likert scale ranging from strongly agree (4) to strongly disagree (1). Also, the 3point scale ranging from always (3) to never (1) was deployed. An in-depth interview was carried out to corroborate some of the responses to the items in the instrument. The instrument has 24 items. Section A sought the views of respondents on adopted human capital resourcing practices. This section has nineteen (19) items. Section B x-rayed the demographic profile of respondents with five (5) items. Cronbach's Alpha or Coefficient Alpha is .89 or $89 \%$. This implies that the instrument is reliable. A total of 105 samples were drawn from the target population using the simple random sampling technique. However 78 questionnaires were returned upon which the data analysis was based. This represents $74 \%$ response rate. Data analysis was carried out with the aid of SPSS (Statistical Package for Social Sciences) version 17. Correlation statistical technique was used to test the hypotheses at $5 \%$ level of significance. 


\section{Results}

\begin{tabular}{|c|c|c|c|c|c|c|c|c|c|}
\hline S/N & STATEMENTS & $\mathbf{N}$ & \multirow{2}{*}{\multicolumn{2}{|c|}{ SA }} & A & D & SD & MIS & STD \\
\hline & & & & & 3 & 2 & 1 & & \\
\hline 1 & $\begin{array}{l}\text { Organisational performance is } \\
\text { positively related to recruitment } \\
\text { practices. }\end{array}$ & 78 & \multicolumn{2}{|c|}{$\begin{array}{c}(35) \\
44.9 \%\end{array}$} & $\begin{array}{c}(40) \\
51.3 \%\end{array}$ & \begin{tabular}{c|c} 
& $(3)$ \\
$\%$ & $3.8 \%$
\end{tabular} & ----- & 3.41 & .57 \\
\hline 2 & $\begin{array}{l}\text { Job analysis exercise (systematic } \\
\text { investigation in to the nature and } \\
\text { requirements of a job) is carried out } \\
\text { prior to recruitment of staff in my } \\
\text { organisation. }\end{array}$ & 78 & \multicolumn{2}{|c|}{$\begin{array}{c}(12) \\
15.4 \%\end{array}$} & $\begin{array}{c}(56) \\
71.8 \%\end{array}$ & $\begin{array}{l}(7) \\
9 \%\end{array}$ & $\begin{array}{c}(3) \\
3.8 \%\end{array}$ & 2.99 & .63 \\
\hline 3 & $\begin{array}{l}\text { Job vacancies are often advertised } \\
\text { externally in my organisation to fill } \\
\text { job openings }\end{array}$ & 78 & \multicolumn{2}{|c|}{$\begin{array}{c}(12) \\
15.4 \%\end{array}$} & $\begin{array}{c}(29) \\
37.2 \%\end{array}$ & \begin{tabular}{l|l}
$\%$ & $(24)$ \\
$\%$ & $30.8 \%$
\end{tabular} & $\begin{array}{c}(13) \\
16.7 \%\end{array}$ & 2.51 & .95 \\
\hline 4 & $\begin{array}{l}\text { Job vacancies are advertised } \\
\text { internally in my organisation to fill } \\
\text { job openings }\end{array}$ & 78 & \multicolumn{2}{|c|}{$\begin{array}{c}(20) \\
25.6 \%\end{array}$} & $\begin{array}{c}(43) \\
55.1 \%\end{array}$ & \begin{tabular}{c|c}
$\%$ & $(13)$ \\
$\%$ & $16.7 \%$
\end{tabular} & $\begin{array}{c}(2) \\
2.6 \%\end{array}$ & 3.04 & .73 \\
\hline 5 & $\begin{array}{l}\text { Both internal and external } \\
\text { recruitment sources are used in } \\
\text { filling job vacancies whenever they } \\
\text { arise. }\end{array}$ & 78 & \multicolumn{2}{|c|}{$\begin{array}{c}(20) \\
25.6 \%\end{array}$} & $\begin{array}{c}(41) \\
52.6 \%\end{array}$ & \begin{tabular}{l|c}
$\%$ & $(15)$ \\
$\%$ & $19.2 \%$
\end{tabular} & $\begin{array}{c}(2) \\
2.6 \%\end{array}$ & 3.01 & .75 \\
\hline 6 & $\begin{array}{l}\text { In the recruitment of staff, my } \\
\text { organisation adopts realistic and } \\
\text { honest recruitment messages. }\end{array}$ & 78 & \multicolumn{2}{|c|}{$\begin{array}{c}(14) \\
17.9 \%\end{array}$} & $\begin{array}{c}(53) \\
67.9 \%\end{array}$ & $\begin{array}{l}(5) \\
6.4 \%\end{array}$ & $\begin{array}{l}(6) \\
7.7 \%\end{array}$ & 2.96 & .75 \\
\hline 7 & $\begin{array}{l}\text { The use of outsourcing recruitment } \\
\text { strategy is practised by my } \\
\text { organisation. }\end{array}$ & 78 & \multicolumn{2}{|c|}{$\begin{array}{c}(18) \\
23.1 \%\end{array}$} & $\begin{array}{c}(34) \\
43.6 \%\end{array}$ & \begin{tabular}{l|c}
)$^{\prime}$ & $(22)$ \\
$\%$ & $28.2 \%$
\end{tabular} & $\begin{array}{c}(4) \\
5.1 \%\end{array}$ & 2.85 & .84 \\
\hline 8 & $\begin{array}{l}\text { The use of contract staff is } \\
\text { commonplace in my organisation }\end{array}$ & 78 & \multicolumn{2}{|c|}{$\begin{array}{c}(19) \\
24.4 \%\end{array}$} & $\begin{array}{l}(32) \\
41 \%\end{array}$ & $\begin{array}{c}(26) \\
33.3 \%\end{array}$ & $\begin{array}{c}(1) \\
1.3 \%\end{array}$ & 2.88 & .79 \\
\hline 9 & $\begin{array}{l}\text { E-recruitment or online or internet } \\
\text { recruitment is practised by my } \\
\text { organisation to attract prospective } \\
\text { applicants from external labour } \\
\text { market }\end{array}$ & 78 & \multicolumn{2}{|c|}{$\begin{array}{c}(19) \\
24.4 \%\end{array}$} & $\begin{array}{c}(10) \\
12.8 \%\end{array}$ & \begin{tabular}{l|l}
$\%$ & $(23)$ \\
$29.5 \%$
\end{tabular} & $\begin{array}{c}(26) \\
33.3 \%\end{array}$ & 2.28 & 1.17 \\
\hline 10 & $\begin{array}{l}\text { Recruitment practices are related to } \\
\text { organisational size }\end{array}$ & 78 & \multicolumn{2}{|c|}{$\begin{array}{c}(21) \\
26.9 \%\end{array}$} & $\begin{array}{c}(44) \\
56.4 \%\end{array}$ & \begin{tabular}{c|c}
$\%$ & $(13)$ \\
$\%$ & $16.7 \%$
\end{tabular} & ----- & 3.10 & .66 \\
\hline 11 & \multicolumn{2}{|l|}{$\begin{array}{l}\text { How often does your organisation } \\
\text { deploy the following internal method(s) } \\
\text { of recruitment? }\end{array}$} & \multicolumn{3}{|c|}{$\begin{array}{c}\text { Always } \\
3\end{array}$} & $\begin{array}{c}\text { Sometimes } \\
2\end{array}$ & $\begin{array}{l}\text { Never } \\
1\end{array}$ & MIS & STD \\
\hline $\mathbf{i}$ & Promotion & & 78 & $\begin{array}{r}(31) \\
39.7\end{array}$ & & $\begin{array}{c}(47) \\
60.3 \%\end{array}$ & ---- & 2.40 & .49 \\
\hline ii & Transfer & & 78 & $\begin{array}{r}(31) \\
39.7 \\
\end{array}$ & & $\begin{array}{c}(44) \\
56.4 \%\end{array}$ & $\begin{array}{c}(3) \\
3.8 \%\end{array}$ & 2.36 & .56 \\
\hline iii & Job posting & & 78 & $\begin{array}{r}(23) \\
29.5 \\
\end{array}$ & & $\begin{array}{c}(50) \\
64.1 \%\end{array}$ & $\begin{array}{c}(5) \\
6.4 \%\end{array}$ & 2.23 & .56 \\
\hline
\end{tabular}




\begin{tabular}{|c|c|c|c|c|c|c|c|}
\hline $\mathbf{S} / \mathbf{N}$ & STATEMENTS & $\mathbf{N}$ & SA & A & D & SD & MIS \\
\hline & & & 4 & 3 & 2 & 1 & \\
\hline iv & Employee referral & 78 & $\begin{array}{c}(12) \\
15.4 \%\end{array}$ & $\begin{array}{c}(55) \\
70.5 \%\end{array}$ & $\begin{array}{c}(11) \\
14.1 \%\end{array}$ & 2.01 & .55 \\
\hline 12 & $\begin{array}{l}\text { How often does your organisation } \\
\text { deploy the following external } \\
\text { method(s) of recruitment? }\end{array}$ & $\mathbf{N}$ & $\begin{array}{c}\text { Always } \\
3\end{array}$ & $\begin{array}{c}\text { Sometimes } \\
2\end{array}$ & $\begin{array}{c}\text { Never } \\
1\end{array}$ & MIS & STD \\
\hline $\mathbf{i}$ & Advertisement & 78 & $\begin{array}{c}(37) \\
47.4 \%\end{array}$ & $\begin{array}{c}(41) \\
52.4 \%\end{array}$ & ---- & 2.47 & .50 \\
\hline ii & Executive search agency(head hunters) & 78 & $\begin{array}{l}(7) \\
9 \%\end{array}$ & $\begin{array}{c}(50) \\
64.1 \%\end{array}$ & $\begin{array}{c}(21) \\
26.9 \%\end{array}$ & 1.82 & .58 \\
\hline iii & Employee referral & 78 & $\begin{array}{c}(15) \\
19.2 \%\end{array}$ & $\begin{array}{c}(53) \\
67.9 \%\end{array}$ & $\begin{array}{c}(10) \\
12.8 \%\end{array}$ & 2.06 & .57 \\
\hline iv & Through Unions & 78 & $\begin{array}{c}(2) \\
2.6 \% \\
\end{array}$ & $\begin{array}{c}(25) \\
32.1 \% \\
\end{array}$ & $\begin{array}{c}(51) \\
65.4 \% \\
\end{array}$ & 1.37 & .54 \\
\hline $\mathbf{v}$ & Educational Institutions(scouting) & 78 & $\begin{array}{c}(8) \\
10.3 \%\end{array}$ & $\begin{array}{c}(31) \\
39.7 \%\end{array}$ & $\begin{array}{l}(39) \\
50 \%\end{array}$ & 1.60 & .67 \\
\hline vi & Private employment agency & 78 & $\begin{array}{c}(9) \\
11.5 \%\end{array}$ & $\begin{array}{l}(46) \\
59 \%\end{array}$ & $\begin{array}{c}(23) \\
29.5 \%\end{array}$ & 1.82 & .62 \\
\hline vii & Public employment agency & 78 & $\begin{array}{c}(5) \\
6.4 \%\end{array}$ & $\begin{array}{c}(25) \\
32.1 \%\end{array}$ & $\begin{array}{c}(48) \\
61.5 \%\end{array}$ & 1.45 & .62 \\
\hline viii & Professional bodies & 78 & $\begin{array}{c}(6) \\
7.7 \%\end{array}$ & $\begin{array}{c}(35) \\
44.9 \%\end{array}$ & $\begin{array}{c}(37) \\
47.4 \%\end{array}$ & 1.60 & .63 \\
\hline ix & Unsolicited applications & 78 & $\begin{array}{c}(4) \\
5.1 \% \\
\end{array}$ & $\begin{array}{c}(53) \\
67.9 \% \\
\end{array}$ & $\begin{array}{c}(21) \\
26.9 \% \\
\end{array}$ & 1.78 & .53 \\
\hline $\mathbf{x}$ & Walk-in & 78 & $\begin{array}{c}(3) \\
3.8 \%\end{array}$ & $\begin{array}{c}(59) \\
75.6 \%\end{array}$ & $\begin{array}{c}(16) \\
20.5 \%\end{array}$ & 1.83 & .47 \\
\hline 13 & $\begin{array}{l}\text { How often does your organisation use } \\
\text { the following recruitment metrics to } \\
\text { determine the effectiveness and } \\
\text { efficiency of recruitment } \\
\text { sources/methods in your organisation? }\end{array}$ & $\mathbf{N}$ & $\begin{array}{c}\text { Always } \\
3\end{array}$ & $\begin{array}{c}\text { Sometimes } \\
2\end{array}$ & $\begin{array}{c}\text { Never } \\
1\end{array}$ & MIS & STD \\
\hline $\mathbf{i}$ & Yield ratio & 78 & $\begin{array}{c}(19) \\
24.4 \%\end{array}$ & $\begin{array}{l}(39) \\
50 \%\end{array}$ & $\begin{array}{c}(20) \\
25.6 \%\end{array}$ & 1.99 & .71 \\
\hline ii & Cost per hire & 78 & $\begin{array}{c}(13) \\
16.7 \% \\
\end{array}$ & $\begin{array}{l}(39) \\
50 \% \\
\end{array}$ & $\begin{array}{c}(26) \\
33.7 \%\end{array}$ & 1.83 & .69 \\
\hline iii & Survey & 78 & $\begin{array}{c}(3) \\
3.8 \%\end{array}$ & $\begin{array}{c}(28) \\
35.9 \%\end{array}$ & $\begin{array}{c}(47) \\
60.3 \% \\
\end{array}$ & 1.44 & .57 \\
\hline iv & Data on turnover & 78 & $\begin{array}{c}(13) \\
16.7 \%\end{array}$ & $\begin{array}{c}(45) \\
57.7 \%\end{array}$ & $\begin{array}{c}(20) \\
25.6 \%\end{array}$ & 1.91 & .65 \\
\hline $\mathbf{v}$ & Leads or applicant generated & 78 & $\begin{array}{l}(7) \\
9 \% \\
\end{array}$ & $\begin{array}{c}(31) \\
39.7 \%\end{array}$ & $\begin{array}{c}(40) \\
51.3 \% \\
\end{array}$ & 1.58 & .66 \\
\hline
\end{tabular}




\begin{tabular}{|c|c|c|c|c|c|c|c|c|c|}
\hline & & $\mathbf{N}$ & SA & \multicolumn{2}{|c|}{ A } & D & SD & MIS & STD \\
\hline & & & 4 & \multicolumn{2}{|r|}{3} & 2 & 1 & & \\
\hline 14 & $\begin{array}{l}\text { There is positive relationship } \\
\text { between selection practices and } \\
\text { organisational performance }\end{array}$ & 78 & $\begin{array}{c}(28) \\
35.9 \%\end{array}$ & \multicolumn{2}{|c|}{$\begin{array}{c}(49) \\
62.8 \%\end{array}$} & $\begin{array}{c}(1) \\
1.3 \%\end{array}$ & ---- & 3.35 & .51 \\
\hline 15 & $\begin{array}{l}\text { Selection practices are related to } \\
\text { organisational size }\end{array}$ & 78 & $\begin{array}{c}(12) \\
15.4 \%\end{array}$ & \multicolumn{2}{|c|}{$\begin{array}{c}(51) \\
65.4 \%\end{array}$} & $\begin{array}{c}(15) \\
19.2 \%\end{array}$ & ---- & 2.96 & .59 \\
\hline 16 & $\begin{array}{l}\text { Employees' tenure in an } \\
\text { organisation is related to adopted } \\
\text { recruitment and selection } \\
\text { practices }\end{array}$ & 78 & $\begin{array}{l}(5) \\
6.4 \%\end{array}$ & \multicolumn{2}{|c|}{$\begin{array}{c}(35) \\
44.9 \%\end{array}$} & $\begin{array}{c}(35) \\
44.9 \%\end{array}$ & $\begin{array}{c}(3) \\
3.8 \%\end{array}$ & 2.54 & .68 \\
\hline 17 & $\begin{array}{l}\text { Orientation/induction of new } \\
\text { staff is done by my organisation }\end{array}$ & 78 & $\begin{array}{c}(34) \\
43.6 \%\end{array}$ & \multicolumn{2}{|c|}{$\begin{array}{c}(40) \\
51.3 \%\end{array}$} & $\begin{array}{c}(3) \\
3.8 \%\end{array}$ & $\begin{array}{c}(1) \\
1.3 \%\end{array}$ & 3.37 & .63 \\
\hline 18 & $\begin{array}{l}\text { Staff are properly placed after } \\
\text { selection in jobs for which they } \\
\text { are economically most useful }\end{array}$ & 78 & $\begin{array}{c}(20) \\
25.6 \%\end{array}$ & \multicolumn{2}{|c|}{$\begin{array}{c}(50) \\
64.1 \%\end{array}$} & $\begin{array}{c}(8) \\
10.3 \%\end{array}$ & ---- & 3.15 & .58 \\
\hline 19 & $\begin{array}{c}\text { How often does your organisation } \\
\text { use the following selection } \\
\text { method (s) in making hiring } \\
\text { decisions? }\end{array}$ & $\mathbf{N}$ & \multicolumn{2}{|c|}{$\begin{array}{c}\text { Always } \\
3\end{array}$} & \multicolumn{2}{|c|}{$\begin{array}{c}\text { Sometimes } \\
2\end{array}$} & $\begin{array}{l}\text { Never } \\
1\end{array}$ & MIS & STD \\
\hline $\mathbf{i}$ & Interview & 78 & $\begin{array}{r}(69 \\
88.5\end{array}$ & & & $\begin{array}{l}9) \\
5 \%\end{array}$ & ----- & 2.88 & .32 \\
\hline ii & Emplo & 78 & $\begin{array}{r}(56 \\
71.8 \\
\end{array}$ & & & 1) $9 \%$ & $\begin{array}{c}(1) \\
1.3 \%\end{array}$ & 2.71 & .49 \\
\hline iii & $\begin{array}{c}\text { Assessment centre (case analysis, } \\
\text { in-basket, leaderless group } \\
\text { discussions) }\end{array}$ & 78 & $\begin{array}{r}(20 \\
25.6\end{array}$ & & & $\begin{array}{l}8 \% \\
7 \%\end{array}$ & $\begin{array}{c}(20) \\
25.6 \%\end{array}$ & 2.00 & .72 \\
\hline iv & Work sample(practical test) & 78 & $\begin{array}{r}(19 \\
24.4\end{array}$ & & & $\begin{array}{l}4 \% \\
4 \%\end{array}$ & $\begin{array}{c}(15) \\
19.2 \%\end{array}$ & 2.05 & .66 \\
\hline $\mathbf{v}$ & $\begin{array}{l}\text { Graphology(hand writing } \\
\text { analysis) }\end{array}$ & 78 & $\begin{array}{r}(10 \\
12.8\end{array}$ & & & $\begin{array}{l}99) \\
2 \%\end{array}$ & $\begin{array}{l}(39) \\
50 \%\end{array}$ & 1.63 & .71 \\
\hline vi & $\begin{array}{c}\text { Polygraph( honesty or integrity } \\
\text { test) }\end{array}$ & 78 & $\begin{array}{r}(15 \\
19.2 \\
\end{array}$ & & & $\begin{array}{l}5) \\
1 \% \\
\end{array}$ & $\begin{array}{c}(38) \\
48.7 \%\end{array}$ & 1.71 & .78 \\
\hline vii & Medical examination & 78 & $\begin{array}{r}(50 \\
64.1\end{array}$ & & & $\begin{array}{l}0) \\
6 \%\end{array}$ & $\begin{array}{c}(8) \\
10.3 \%\end{array}$ & 2.54 & .68 \\
\hline viii & Reference report & 78 & $\begin{array}{r}(33 \\
42.3\end{array}$ & & & $\begin{array}{l}3 \%) \\
2 \%\end{array}$ & $\begin{array}{c}(9) \\
11.5 \%\end{array}$ & 2.31 & .67 \\
\hline ix & $\begin{array}{c}\text { Investigation from previous } \\
\text { employers }\end{array}$ & 78 & $\begin{array}{r}(27 \\
34.6\end{array}$ & & & .0) & $\begin{array}{c}(11) \\
14.1 \%\end{array}$ & 2.21 & .67 \\
\hline
\end{tabular}

Source: Field Survey, 2011.

Legend: $\mathrm{N}=$ Respondents: $\mathrm{SA}=$ strongly agree: $\mathrm{A}=$ Agree: $\mathrm{D}=$ disagree: $\mathrm{SD}=$ strongly disagree:

MIS= mean Item Score: $\mathrm{STD}=$ standard deviation/ variation ratio

Table 1. Descriptive Statistics of Primary Data 


\begin{tabular}{|c|c|c|c|}
\hline $\mathrm{S} / \mathrm{N}$ & Variables & $\begin{array}{l}\text { Absolute } \\
\text { Frequency }\end{array}$ & $\begin{array}{l}\text { Relative } \\
\text { Frequency }\end{array}$ \\
\hline \multirow{3}{*}{1.} & $\underline{\text { Sex of Respondents }}$ & & \\
\hline & Male & 69 & $88.5 \%$ \\
\hline & Female & 9 & $11.5 \%$ \\
\hline \multirow{6}{*}{2.} & Age of Respondents & & \\
\hline & Less than 20years & ----- & --- \\
\hline & $20-29$ & 4 & $5.1 \%$ \\
\hline & $30-39$ & 48 & $61.5 \%$ \\
\hline & $40-49$ & 25 & $32.1 \%$ \\
\hline & 50 and above & 1 & $1.3 \%$ \\
\hline \multirow{5}{*}{3.} & $\underline{\text { Marital Status }}$ & & \\
\hline & Married & 49 & $62.8 \%$ \\
\hline & Single & 29 & $37.2 \%$ \\
\hline & Separated & -- & --- \\
\hline & Divorced & --- & ---- \\
\hline \multirow{6}{*}{4.} & Qualifications & & \\
\hline & OND & 1 & $1.3 \%$ \\
\hline & HND & 30 & $38.5 \%$ \\
\hline & First degree & 27 & $34.6 \%$ \\
\hline & Masters & 20 & $25.6 \%$ \\
\hline & Ph.D & --- & ---- \\
\hline \multirow[t]{4}{*}{5.} & Job Category & & \\
\hline & Junior & ----- & --- \\
\hline & Senior & 62 & $79.5 \%$ \\
\hline & Management Staff & 16 & $20.5 \%$ \\
\hline
\end{tabular}

Source: Field Survey, 2011.

Table 2. Demographic Profile of Respondents 
In testing the first hypothesis that there is a positive relationship between recruitment practices and organisational performance, it was found that there is a positive relationship between recruitment practices and organisational performance $(\mathrm{r}=0.45 ; \mathrm{p}<.05)$. This result is statistically significant. In testing the second hypothesis that there is a positive relationship between selection practices and organisational performance, it was found that there is a positive relationship between selection practices and organisational performance $(r=0.49$; $\mathrm{p}<.05)$.This is also statistically significant. This means that as recruitment and selection practices are properly executed or improve, so does organisational performance. It should be noted that this interpretation in no way implies causality. The significant relationship merely indicates that the variables covary.

\section{Discussion of findings}

From the test of hypotheses, it was found that there is a positive relationship between recruitment practices and organisational performance $(\mathrm{r}=0.45 ; \mathrm{p}<.05)$. It was also found that there is a positive relationship between selection practices and organisational performance $(\mathrm{r}=0.49 ; \mathrm{p}<.05)$. These results are statistically significant. These findings are consistent with the findings of Delany and Huselid (1996) who found that practising an effective recruitment and selection process has positive relationship with organisational performance. The findings also corroborate the views of Terpstra and Rozell (1993) who found an association between use of recruitment and selection procedure and profits. The findings are also consistent with those of Ahmed and Schroeder (2003) who investigated the effect of selective hiring on organisational performance (quality, cost, flexibility, delivery and commitment) and found a positive and significant relationship with firms' operational performance.

\section{Conclusion}

This study set out to investigate human capital resourcing practices and organisational performance. From the findings of this study, it could be concluded that there is an association between human capital resourcing practices and organisational performance. From the findings of this study, the authors hereby recommend that organisations should pay adequate attention to recruitment and selection practices to gain competitive advantage.

\section{References}

Aamodt, M.G. (1999). Applied Industrial/ Organisational Psychology. (3rd ed). U.K: Wadsworth Publishing Company.

Ahmed, O. \& Schroeder, R.G. (2003). “The Impact of Human Resource Management Practices on Operational Performance: Recognising Country and Industry Differences". Journal of Operations Management. 21, pp. 19-43.

Armstrong, M (2009). Armstrong's Handbook of Human Resource Management Practice. (11 ${ }^{\text {thed.). }}$ U.K: Kogan Page Ltd.

Armstrong, M. (2001). A Hand Book of Human Resources Management Practice (8th ed). U.K: Kogan Page Ltd. 
Armstrong, M. (1998). Managing People: A Practical Guide for Line Managers. U.K: Kogan Page Ltd.

Asika, N. (1991). Research Methodology in the Behavioural Sciences. Lagos: Longman Nigeria Plc.

Barney, J.B. (2001). "Resource-based Theories of Competitive Advantage: A Ten-Year Retrospective on the Resource-based View". Journal of Management. (27), pp. 643650.

Bontis, N., Dragonetti, N.C., Jacobsen, K. \& Roos, G. (1999). “The Knowledge Toolbox: A Review of the Tools Available to Measure and Manage Intangible Resources." European Management Journal. 17(14), pp. 391-402

Chidi, O.C \& Ogunyomi, P.O. (2010). "Research and Organisational Development as Pivots of Corporate Growth and Effectiveness in Nigerian Organisations". European Journal of Scientific Research.Vol.44, №.1, pp.152-158.

Delaney, J.T. \& Huselid, M.A. (1996). “The Impact of Human Resource Management Practices on Perceptions of Organisational Performance". Academy of Management Journal. Vol.39, № 4. pp. 949-969.

Dess, G.G., \& Shaw, J.D. (2001) “Voluntary Turnover, Social Capital and Organisational Performance." Academy of Management Review. 26(3), pp.446-456

Dessler, G. (2008). Human Resource Management. (11 th ed.). New Delhi: Prentice-Hall of India Private Ltd.

Dreher, F.G. \& Dougherty, T.W. (2002). Human Resource Strategies: A Behavioural Perspective for the General Manager. New York: McGraw-Hill/Irwin.

Etomi, E. (2002). "The Changing Face of Recruitment and Selection". Human Resource Management, Journal of the Institute of Personnel Management of Nigeria.Vol.11, No.1, pp.26-33.

Etzioni, A. (1964). Modern organisations. Englewood Cliffs NJ: Prentice Hall.

Fajana, S. (1995). "Managing Human Resource for Productivity in Small and Medium Sized Enterprises."In Ojo. A.T (ed) Management of Small and Medium Scale Enterprises in Nigeria (pp.121-134). Lagos: Pumark Nig. Ltd (Educational Publishers)

Fashoyin, T. (2005). "Management in Africa". Lagos Organisation Review.Vol.1, No.1, pp.43-45

Gberevbie, D.E. (2010). "Strategies for Employee Recruitment, Retention and Performance: Dimension of the Federal Civil Service of Nigeria". African Journal of Business Management.Vol.4 (8).pp.1447-1456.

Gberevbie, D.E. (2006). "Recruitment and Quality Academic Staff Selection: The Case Study of Covenant University. Ife Psychologia. Vol.14, №. 2, pp.117-141.

Harel, G.H. and Tzafrir, S.S. (1996). "The Effects of Human Resource Management Practices on the Perceptions of Organisational and Market Performance of the Firm". Human Resource Management. 38, pp.185-200.

Hornsby, J.S., \& Kurato, D.F. (1990). “Human Resource Management in Small Business: Critical Issues for the 1990s".Journal of Small Business Management.28 (3), pp.9-18.

Huselid, M.A. (1995). “The Impact of Human Resource Management Practices on Turnover, Productivity, and Corporate Financial Performance" Academy of Management Journal, 3(38): 635-672. 
Katou, A. A. (2009). "The Impact of Human Resource Development on Organisational Performance: Test of a Causal Model." Intitute of Behavioural and Applied Management, pp. 335-356.

Katou, A. A. (2008). "Innovation and HRM: The Greek Experience".Organizacija. Vol.41, №.3, pp.81-89

Katou, A. A. \& Budhwar, P. S. (2006). “The Effect of Human Resource Management Systems on Organisational Performance: Test of a Mediating Model", International Journal of Human Resource Management, 17(7), pp. 1223-1253.

Khan, M.A. (2010). "Effects of Human Resource Management Practices on Organisational Performance -An Empirical Study of Oil and Gas Industry in Pakistan". European Journal of Economics, Finance and Administrative Sciences. Issue 24, pp.157-175

Kuchinke, K.P. (2003). "Contingent HRD: Towards a Theory of Validation and Differentiation in Formal Human Resource Development". Human Resource Development Review. 2(3), pp.294-309

Mathias, R.L \& Jackson, J.H. (2004). Human Resource Management. (10th ed). Cincinnati, Ohio: South-Western Publishing.

Noe, R. A., Hollenbeck, J.R., Gerhart, B. \& Wright, P.M. (2004). Fundamentals of Human Resource Management. New York: McGraw - Hill/ Irwin.

Nwachukwu, C. C. (2000), Human Resources Management. (2nd ed). Nigeria: Davidstones Publishers

Oladipo, J.A \& Abdulkadir, D.S. (2011). “An Evaluation of Strategic Human Resource Management in Nigerian Universities: The Impact of Ownership Type and Age". European Journal of Economics, Finance and Administrative Sciences. Issue 32, pp.7-25.

Osterman, P. (1994). "How Common is Workplace Transformation and Who Adopts It?" Industrial and Labour Relations Review. 47: 173-88.

Oyeniyi, A.A. (2006). “The Influence of Students' Industrial Work Experience Scheme (SIWES) on the Development and Utilisation in Oyo and Osun States, Nigeria." Unpublished Ph.D Thesis, University of Ibadan.

Paauwe, J. (2004). HRM and Performance: Achieving Long-term Viability. Oxford: Oxford University Press.

Peretomode, V.F \& Peretomode, O. (2001). Human Resources Management: Principles, Policies and Practice, Lagos: Onosomegbowho Ogbinaka Publishers.

Pfeffer, J. (1994). Competitive Advantage Through People. Boston: Harvard Business School Press.

Ployhart, R.E. (2006). "Staffing in the 21 st Century: New Challenges and Strategic Opportunities." Journal of Management. Vol. 32, № .6, pp.868-897.

Price, A. (2004). Human Resource Management in a Business Context. (2nd ed). London: Thomson Learning.

Terpstra, D.E. \& Rozell, E.J. (1993). “The Relationship of Staffing Practices to Organisational Level Measures of Performance." Personnel Psychology. 46, pp. 27-48.

Verburg, R.M. (1998). Human Resource Management: Optimale HRM-praktijken en Configuraties. Dissertation. Amsterdam: Vrije Universiteit. 
Wang, F., Chich-Jen, S., \& Mei-Ling, T. (2010). “Effect of Leadership Style on Organisational Performance as viewed from Human Resource Management Strategy". African Journal of Business Management .Vol. 4(18), pp. 3924-3936

Yoder, D. \& Staudohar, P.D. (1982). Personnel Management \& Industrial Relations. (7th ed.). Englewood Cliffs, N.J: Prentice-Hall Inc. 
(C) 2012 The Author(s). Licensee IntechOpen. This is an open access article distributed under the terms of the Creative Commons Attribution 3.0 License, which permits unrestricted use, distribution, and reproduction in any medium, provided the original work is properly cited. 